This year would begin "Phase II" of the Area Centers Program. In this phase a maximum of only five or six Centers in each area would be assisted by the federal government, or around fifty in total, as compared to the present 106 Centers. The choice of which Centers to be assisted would depend on a number of factors - academic excellence, geographic location, breadth of program, and faculty and institutional support, among others. The field of choice would be entirely open in that new applications would be entertained from all existing Centers, as well as from programs which are not at present receiving Federal assistance. It was stressed that the Centers receiving aid would have to have a broad disciplinary spread regardless of the excellence of any particular field. The group was assured that the academic community would have a voice in the selection of those Centers to be assisted.

Some stress will be laid in the coming years on innovative and pilot programs, particularly at the undergraduate level. It is anticipated that the program of NDEA Fellowships will be continued probably under somewhat different format than at present and pro$v$ ision will be made also for summer programs in language and for research. The overall aim of the "Phase II" program will be to broaden and deepen the facilities of the Centers to be assisted so that a continuing, although possibly restricted (as compared to past years), number of area specialists may become available over the next few years.

The overall question of continued national government assistance to international studies programs received a great deal of attention from the group. The point was strongly made that both Congress and the Bureau of the Budget are becoming increasingly reluctant to support categorical grants - that is to say, grants of Federal funds for specific educational objecrives. The general tone of legislation in support of higher education now pending before Congress lays stress on bloc grants to institutions of higher education for general support rather than for specific purposes. Should this legislation become a reality the implication is that area studies will have to take its chances along with all other programs in terms of the priorities of particular institutions. The area studies director will find himself, then, contending with directors of other types of programs within his own institution for a share of the university budget, and his success will depend on his ability to argue his own case forcibly before the administration of his university.

If categorical support for area studies is to continue, it will require coordinated, forceful and continuous presentation of the merits of the case before Congress by the educational community interested in area studies. The exact form which this presentation may take remains far from decided at this point, but it will be the task of the Area Studies Associations and other interested bodies to assist in determining the most effective organizational structure which can be created for this purpose.

$* * * * * *$

\title{
News from the Committee on the Status of Women
}

The Committee on the Status of Women of the African Studies Association, as provided under votes of the Association at the 1971 Annual Meeting, has had as one of its tasks a concern with improving employment possibilities for women. Preliminary statistics have indicated that women have not been hired in equitable numbers in comparison with the available supply of Ph.D.'s. The Committee has found that a good bit of the time of individual members of the Committee this year has been spent in advocating fed- 
eral legislation concerning the status of women. While not directly connected with ASA activities, some of the Committee members have felt that this legislation would have long-term affects of considerable import to institutions and individuals affiliated with the Association.

The Committee would like to draw the attention of the membership to Title VII of the Civil Rights Act of 1964, as amended March 1972. Title VII forbids discrimination in employment on the grounds of race, color, religion, sex or national origin, and educational institutions are now included. The new provisions apply to all educational institutions, both public and private. Institutions are covered regardless of whether or not they have any federal funds. (Previously, persons wishing to charge sex discrimination or other discriminatory employment practices had to rely on Executive Order 11246 as amended, which forbade discrimination for all federal contractors. This executive order gave rise to the now familiar complaints against some 350 universities through HEW.) Title VII as amended is enforced by the Equal Employment Opportunities Commission (EEOC) which receives and investigates charges of discrimination. The Commission has the power to bring civil action against a private institution in the appropriate Federal District Court. Mechanisms are also provided for achieving relief from public institutions. Powers of reinstatement of employees and awarding of backpay are found in the new legislation. There is also a provision which prevents harrassment of employees who have filed a complaint under this Title. Employers are forbidden to discriminate against those so doing.

Jobs may not be restricted on the basis of sex for any of the following reasons:

1. Assumptions related to the applicant's sex, e.g. some or most members are unable or unwilling to do the job.

2. Preference of co-workers, employers, clients or customers.

3. The job has traditionally been restricted to members of the opposite sex.

4. The job involves heavy labor, manual dexterity, late or night hours, work in isolated locations or unpleasant surroundings.

5. Physical facilities are not available for both sexes.

6. The job requires personal characteristics not exclusive to either sex such as tact, charm or aggressiveness.

The Committee on the Status of Women realizes that this is a lean year; however, attempts are presently being made to establish a mechanism for a yearly assessment of hiring practices. The Committee requests information from department chairmen and directors of programs of African studies in the following two employment areas:

I. Placement

A. Total number of students seeking placement in African studies

1. Number of female students seeking placement

2. Number of male students seeking placement

B. Number of ABD (all but dissertation) or degree holders placed

1. Number of male students placed

2. Number of female students placed

Comments 
I1. Hiring
A. Number of positions open in African studies (and related departments)
B. Hiring methods
1. Open recruitment (e.g. ad in ASA Newsletter)
Other
2. Number of resumes/papers from female candidates received or obtained
3. Number of male/female candidates interviewed for each vacancy
(name position)
4. Total number hired
Number of men
Number of women
Comments
This information should be sent to the ASA Secretariat for forwarding to the
Committee.

Another finding of the Committee has been the need to locate those who are equipped to provide information about women in Africa. It is our view that research on women in Africa has not been sufficient to answer many important questions. In this connection, one of the Committee members is co-chairing a panel on women at the Annual Meeting in Philadelphia next November. The panel is seeking, through open advertisement, to locate research about women and to discover problems connected with this sort of research. The title of the panel is "Research Priorities: Where are Women's Studies in Africa?" If you can participate in the panel, whether providing a paper, short report, or as a discussant, please write directly to Professor Barbara Callaway, 1304 South Beverly Glen, Los Angeles, California 90024. If you cannot participate, please communicate with us concerning any past or current research on women in Africa.

The Committee urges women members of the ASA to communicate with us over the summer with suggestions about implementation of any of our resolutions. Write either through the ASA offices or directly to Dr. Emily Card, 988 Noria Street, Laguna Beach, California 92651.

\section{Major Collections at the Center for African Oral Data} Archives of Traditional Music, Indiana University, Bloomington, Indiana

Some of the material at the Center was processed on a grant from the Ford Foundation to the Oral Data Committee of the African Studies Association. Information as to the availability of specific collections may be obtained by writing to the Associate Director of the Archives, Mr. Frank Gillis. Since use of most of the collections is restricted through agreements signed by the collectors with the Archives, scholars wishing dubs must request permission directly from the individual collector(s). Mr. Gillis will provide the necessary addresses. There is a minimum charge of $\$ 6.00$ per tape reel (less $20 \%$ for depositors), plus costs for copies of documentation, shipping, insurance and handling. 